\title{
Gendering Technologies: Women In Cameroon's Pink-Collar ICT Work
}

\author{
Manka E. Tabuwe, University of Buea, Cameroon \\ Henry Z. Muluh, University of Buea, Cameroon \\ Enoh Tanjong, University of Buea, Cameroon \\ Patience Akpan-Obong, Arizona State University, USA \\ Lawrence Sikali, The ICT University, USA \\ Augustine Ngongban, The ICT University, USA \\ Ajibike Olubunmi Itegboje, International Center for IT and Development and The ICT University, USA \\ Kibily Demba Samake, Louisiana State University, USA \\ Victor Wacham A. Mbarika, International Center for IT and Development and The ICT University, USA
}

\begin{abstract}
This paper examines the rise of low-skilled, low-paying, female dominated jobs in Cameroon's information and communication technology (ICT) sector. It seeks to understand why and how women (mostly between the ages of 18 and 35) seem to be "naturally" drawn to these jobs, described in the literature as pink-collar jobs. Through interviews with ICT workers and observations at ICT training centers and call centers in Buea, a major city in the Southwest Region of Cameroon, the paper explores the factors that hinder women's entry into more technical ICT jobs in Cameroon. It concludes that some of these factors, such as the prior income level of female ICT workers and the absence of female instructors at ICT training centers, further reinforce gender-based job classifications and the rise of "ghettoization" in Cameroon's ICT sector.
\end{abstract}

Keywords: Pink-Collar ICTS; Gender and Technology; Sub-Saharan Africa; Call Box Operators; Cameroon

\section{INTRODUCTION}

$\mathrm{n}$ development studies, every generation apparently identifies the technology or set of technologies considered to hold the key that unlocks the door to prosperity in developing countries. The list of "wonder technologies" is long and includes; teledensity (the number of landline telephones in use for every 100 individuals living within an area), the radio and television, once hailed as the vehicle through which attitudes of modernization and economic growth would diffuse to countries then emerging from colonization (Akpan-Obong, 2009). Optimism about the utility of these and other technologies was premised on the assumptions that exposure to western economic and political systems through the mass media would inculcate certain attitudes among citizens of underdeveloped countries and orient them toward savings and investments. These were the mechanisms for economic growth, as advanced by modernization and communication theorists of the 1960s (such as Rostow, 1963 and Lerner, 1965). The assumptions about the role of the telephone, radio, television and similar technologies focused on consumption rather than on production (of technologies and content). This laid a foundation for developing countries that persists today as theorization in development studies now focuses on information and communication technologies (ICTs) as tools for socioeconomic growth in developing countries particularly those in Sub-Saharan Africa, the poorest region in the world. Africa has been identified as a continent that consumes what it does not produce and produces what it does not consume (Institute of International Studies of Missouri Southern State College, 2002). In his widely watched documentary, "The Africans: A Triple Heritage," and the accompanying books, Mazrui argues that the tragedy of Africans is that they cultivate taste for western products and lifestyles without acquiring the technological skills to support the new tastes and lifestyles (Mazrui, 2009).

While ICTs could potentially create opportunities for Africans to be involved in production of technologies in all their dimensions and content in the global economy, the emphasis on how they engage with ICTs remains on 
consumption and usage. Thus postulations about the capacities of ICTs to stimulate socio-economic growth in developing countries are often framed in narratives of consumption and usage rather than production. Studies have accordingly showcased projects and strategies through which countries are utilizing ICTs to achieve growth in different sectors of the society. Common research questions concern not just the level of usage (diffusion) but also the sophistication and purpose of usage (Choudhury, 2009). At the systematic level, there are issues of the impact of the diffusion of different ICTs, such as the cellular phone on different sectors of the society.

This research takes the discourse beyond mere consumption to examine how ICTs can provide certain groups of people with the tools to produce - knowledge/content or artifacts. The understanding is that consumption can be empowering when it offers users of technology vital skills that can apply to production in other spheres of the economy. Obviously, skills are often transferred through an educational environment, hence the inclusion of ICT training centers in this research. We have examined two contexts of ICT usage in Cameroon: the activities of call box operators and of those employed in call centers owned and operated by other businesses (within and outside the ICT sector). The bulk of the research therefore focuses on female employment in the telecommunication sector, specifically the cellular phone, the technology that has been most pervasive in the country, reflecting the continental trend.

The focus of the research on women is based on a major theoretical assumption in the ICT for development (ICTD) literature concerning the potential of the technologies to level the playing field for traditionally disadvantaged groups (of countries and people). Women everywhere but particularly in Sub-Saharan Africa fall into the category of the traditionally disadvantaged. There is an additional level of marginalization in the discussion of technologies and women. The literature on gender and technology indicates how women have traditionally been excluded from this sphere (Spender, 1996; Hafkin \& Taggart, 2001; Bury, 2011). Interestingly though, the spread of call centers and other IT-enabled services (ITES) in developing countries has increased the number of women in the information Technology sector. This opens up new areas of criticisms in the literature about the quality of work and the extent to which ITES empowers women or reinforce existing societal marginalization. While this topic is outside the scope of this study, one directs attention to extensive studies from South-East Asia that explores this issue ( $\mathrm{Ng} \&$ Mitter, 2005).

This research incorporates quantitative and qualitative methods for a gender analysis of the ICT workforce in Cameroon through case studies in Buea, a major city in the South Western Region. It identifies ICT jobs and skills that are performed predominantly by women. Who are the women who work in pink-collar jobs? What factors draw them into these jobs? What are their choices and what issues do they grapple with in the industry? Data for the research were generated through interviews with call box (fixed wireless public payphones) operators, workers in call centers and ICT trainers. Other research methods were content analysis of enrollment materials at ICT training centers and observations. The results of the research are presented in this paper, but first we begin with an overview of ICT diffusion in sub-Saharan Africa, gender and ICTs and the potential for women's empowerment through ICTs.

\section{DIFFUSION OF ICTS IN SUB-SAHARAN AFRICA}

There is a general consensus amongst sceptics of the ICTD literature, that more effective and efficient use of the technologies will stimulate economic growth and development (Arundhathi, et al 2010). There is also agreement that African countries will continue to engage with the technologies as consumers rather than as producers. The rate of innovation in ICT production is so rapid that before developing countries can catch up, the technologies have advanced to newer heights. Given this reality, many African countries seem to be exploring various strategies through which usage can result in productive endeavours in other sectors. For instance, in the past when radio and television were the "new ICTs," they were used in agricultural extension services and long distance education. In recent times, as the literature in online education indicates, the Internet has been used as virtual classrooms for resource sharing. Of course, this assumes that people in far-flung places in sub-Saharan Africa have access to the Internet and have the literacy and primary technologies (such as electricity) to utilize and benefit from these platforms. The reality though is that access to the Internet and many ICTs is hindered by many factors. Conversely, the cellular phone is a technology that overcomes many of the constraints of the other ICTs and this is why its usage has spread exponentially in Africa over the last ten years. For instance, unlike the Internet, one does 
not have to be literate in any language in order to use a cell phone. This explains why penetration rates of cellular phones in Africa reached $41 \%$ at the end of 2010 compared with $9.6 \%$ for Internet penetration. The comparatively lower rate of Internet penetration reflects the equally depressing rate of broadband penetration level of less than one percent for 2010 (ITU, 2011).

While the penetration rate of the cellular phone in Africa is significant, it still lags behind the global rate (76\%) and that of developing countries (68\%, generated mostly by the Asia and Pacific region). Still, the continent has made giant strikes against the backdrop that in 1999, most African countries had no mobile phone coverage at all. Indeed, only six years ago (2005), the penetration rate for cellular phone on the continent was less than 13\%, incidentally the penetration level for Cameroon in 2005. The continental trend reflects that of Cameroon in other years as well. As Table 1 indicates, the cumulative annual growth (CAGR) of mobile cellular subscriptions is exponentially higher than that of estimated Internet usage. Indeed, internet usage level in 2009 is lower than that of cell phone subscription in Cameroon in 2002. This development in the mobile telephone sector has generated much research and policy interest.

Table 1: Ten-Year Trend in Mobile Cellular and Internet Penetration in Cameroon

\begin{tabular}{|c|c|c|}
\hline Year & Subscriptions Per 100 Inhabitants & Estimated Internet Users Per 100 Inhabitants \\
\hline 2000 & 0.65 & 0.25 \\
\hline 2001 & 2.57 & 0.28 \\
\hline 2002 & 4.22 & 0.36 \\
\hline 2003 & 6.33 & 0.59 \\
\hline 2004 & 8.79 & 0.98 \\
\hline 2005 & 12.64 & 1.40 \\
\hline 2006 & 17.19 & 2.03 \\
\hline 2007 & 24.31 & 2.93 \\
\hline 2008 & 32.28 & 3.80 \\
\hline 2009 & 41.0 & 3.84 \\
\hline 2010 & -- & -- \\
\hline
\end{tabular}

Source: International Telecommunication Union, 2011

The rapid diffusion of the cellular phone has created spillover effects on local economies that may ultimately impact on a country's economy at the macro level. One of these effects is a factor of the very nature of cell phone usage in many Sub-Saharan African countries. As noted by many researchers (such as Sutherland, 2007), most cell phone users in these countries are pre-paid customers. About $98 \%$ of cell phone users in Nigeria are prepaid customers, loading up credit on their phones with recharge cards marketed by the mobile phone service providers through intermediaries. This has led to an emergence of a vibrant market in recharge cards in many SubSaharan African countries. Sales in these cards have created many non-skilled jobs for young people with women dominating in many countries. Few studies have however been done on how this new sub-sector impacts on the lives of those engaged in it though anecdotal reports abound of the significant improvement in the quality of lives of individuals and small business. In Ghana for instance, farmers in Tamale are reportedly able to send text messages to inquire about corn and tomato prices in Accra, some 1,000 kilometers away. In Niger, day laborers call acquaintances in Benin to find out about job opportunities without making the expensive cross-border trip. In Malawi, those affected by HIV and AIDS can receive text messages daily, reminding them to take their medicines on schedule. Citizens in countries as diverse as Kenya, Nigeria and Mozambique are able to report violent confrontations via text messages to a centralized server that is viewable, in real time, by the entire world. These effects can be particularly dramatic in rural Africa, where in many places mobile phones have represented the first modern communication infrastructure of any kind. Mobile phones have greatly reduced communication costs, thereby allowing individuals and firms to exchange information quickly and cheaply on a variety of economic, social and political topics. Research shows that the reduction in communication costs associated with mobile phones has tangible economic benefits by improving agricultural and labor market efficiency and producer and consumer welfare in specific circumstances and countries (Jensen, 2007; Aker, 2008; Aker, 2010; Klonner and Nolen, 2008). On another level, the recent political upheaval in Northern Africa also affirms the utility of the cellular technology and Internet in mass mobilization and demonstration. 
In addition to the impact on GDP, there is also the benefit of direct taxation revenue (Cellular Operators Association of India, 2005). The liberalization of policies that facilitate the provision of access through call boxes, telephone booths and "cyber cafés" has created jobs in the service sector. Call boxes alone generated more than 10,000 jobs between 2002 and 2004 in Cameroon (Nzepa \& Keuchantkeu, 2007). As the telecom sector continues to grow, job opportunities for different demographic groups including women increase as many seek employment in ICT-enabled jobs. These are the low-skilled, low-paying activities collectively referred to as pink-collar jobs because of the predominance of women in them. Relative to the choices available to women who work in this subsector, pink-collar jobs are rampant in Cameroon partly as result of the low level of capital required for initial investment, legal set up requirement or ease of recruitment into them. They are generally perceived to directly stimulate the general economy.

Mobile telephony therefore impacts an economy through increased GDP, job creation (both in the mobile industry and the wider economy), improved productivity, and increases revenue. According to Vodafone, a global cellular service provider that conducts business in many African countries, in a typical developing country, a $10 \%$ increase in cell phone usage potentially boosts GDP growth by 6\% (2005). For instance, the Nigerian treasury has generated more than N200 billion in taxes and levies from mobile telephone operators (Ajiboye et al, 2007) since the first roll out of digital mobile services in 2001. While ICTs impact all aspects of the economy, they also have a specific gendered effect on a country's labor workforce. This research explores these gendered implications in Cameroon's ICT work force through the perspectives of ICT training centers, call box operators and call center workers in Buea, a city in the South Western Region of the country. We introduce the case studies with a discussion of the determinants of "women's work" in the ICT sector.

\section{PINK COLLAR JOBS IN ICT AND DETERMINANTS OF WOMEN'S WORK}

According to Howe (1977), pink-collar jobs are traditionally female-dominated, occupational groupings. Pink-collar work includes those of nurses, typists, telephone operators, secretaries, beauticians, waitresses and domestics. ${ }^{1}$ Kleiman (2005) used a comparison of the different kinds of jobs to highlight issues about the pink-collar jobs. The white-collar worker, she argues, is a professional; the blue-collar worker is involved in manufacturing; and the pink-collar person is the lesser category slipping into some sort of ghetto: "the pink-collar ghetto". This ghetto is characterized not only by low pay but also the lack of a career path. Pink-collar jobs can then be defined as jobs that do not require much technical skill. They are "soft" skilled, following a routine pattern of operation after the initial training.

Although women's representation in the global labor force has increased over the decades, women's participation rates are still lower than men's. They are also disproportionately represented in non-standard and lower-paid forms of work, such as temporary and casual employment, part-time jobs, home-based work, selfemployment and work in microenterprises (Huitfeldt et al, 2009). While the rapid expansion of ICTs have offered lots of new jobs for women, these jobs are often low paying and low ranking in the employment hierarchies. Huitfeldt highlights the fact that jobs in hardware and software design are dominated by men while ICT jobs involving repetitive and menial tasks, are predominantly regarded as women's work (Gill 2003). Other studies on women and ICTs also support this and indicate that many women worldwide occupy pink-collar jobs within ICT businesses (Belt et al, 2000; Zapf et al, 2003).

In sub-Saharan Africa a job that has become popular with the advent of mobile phone and internet is working at "cyber cafés". The cyber café is a public ICT access center where customers pay to utilize technologies, such as a computer, phone, Internet browsing or e-mailing. Other customers, especially young people, also use the "cyber café" as a social medium, (Facebook, Skype, LinkedIn etc), meeting point as well as to develop their digital skills. These cafés are managed by people with some basic ICT skills. Research has shown that in most Sub-Saharan African countries, women work as clerks and assistants in many cyber cafés. In Nigeria, they typically perform

\footnotetext{
${ }^{1}$ Obviously, not all pink-collar jobs are low-paying. For instance, nurses in North America are the highest paid professionals in their category. However, nursing is a profession that remains heavily female-dominated even as men in western countries are entering it in large numbers. A "nurse" continues to invoke a female image in popular imaginations even in the West, and more so in Sub-Saharan African countries where male nurses are perceived as anomalies.
} 
book-keeping and secretarial duties, and other simple tasks such as selling air (usage) time tickets to clients and keeping the facilities clean (Akpan-Obong, 2009). Most managers are men and are responsible for trouble-shooting technical problems that customers may encounter. Call center jobs are similar to cyber café jobs to the extent that workers require minimal computer and telephone skills to be able to attend to customers' needs. In both contexts, career progression is limited (Johnson, 2009). Many workers aspire to own their own ICT business, but factors (discussed below) hinder the achievement of this goal.

There are many determinants of entry of women into pink-collar ICT jobs. One of these is the very nature of the jobs themselves and the demands on workers' time. These require less physical input and training. As obtains elsewhere, women are primary caretakers in many households in Sub-Saharan Africa. They are therefore mostly responsible for the overall running of the household including child and elder care (of dependent family members living in the household). These responsibilities determine the kinds of work outside the home that women can engage in giving their need for flexible work schedules. Most employers do not take much into consideration whether a woman is married, has children or not, except when it interferes with their job (Mackeogh and Preson, 2005). The work/life balance therefore becomes a critical factor in hiring decisions. Studies have shown that highly skilled ICT jobs such as program analyst, database administrators, and network managers are not conducive to flexible working conditions such as extended leave or part time. This is particularly so for more skilled functions and senior positions. Even when women are willing to make sacrifices in order to contribute to the financial wellbeing of the family, employers are hesitant about hiring women to skilled positions for fear that their family obligations would interfere with their productivity. The pressure for performance therefore pushes employers to target "risk-free" workers who are predominantly male to occupy strategic positions at the expense of women applicants.

Many of the ICT-related jobs occupied by women in developing countries are characterized by social factors. For instance, culturally, some jobs are viewed as more fitting for one gender over another. Assumptions are already being made in developing countries about which occupations are most suitable for men and women, and these assumptions may be a determining factor for men and women in the selection of an IT career path (Ng and Mitter, 2005). Women tend to be well represented in desktop publishing and software programming, but not in hardware design, operating systems, or computer maintenance. Miller et al (2004) attribute this segregation largely to parental attitudes and the image attached to some sectors as science, engineering and IT (Spender, 1996; Johnson, 2009; Bury, 2011). Male technical training teachers in Brazil, for example see software, graphics, and desktop publishing as more "female," while associating hardware design and its maintenance with men. According to Hafkin and Taggart (2001), data from South Africa also show a gender division in the IT sector. While women make up to 26 percent of IT employees overall in South Africa, they make up only 19 percent in data communication and networking jobs - the third lowest representation in IT jobs. Next to hardware and computer architecture (14 percent), is information systems and information technology management (18 percent). They are best represented in education, training, and development (39 percent), end user computing (36 percent), and sales and marketing (36 percent).

Other social factors relating to culture suggest that certain female-oriented skills are less valuable and ICT jobs that use these skills have a lower status. Panteli et al (2001) argue that roles in the ICT industry, such as project and consulting work, which are human-oriented and require the "feminine" attributes of good communication skills, flexibility and a collaborative style, are considered as having lower status than the more technical roles that men typically hold. Such a perception has a disadvantage for women because it creates "gendered" jobs within the ICT industry. Though Von Hellens et al (2000) consider this as a positive factor when trying to encourage women to seek the possibilities of a career in ICT that would be enhanced by these "feminine" skills. This probably explains the rise of ITES in South East Asia, a region that has notably become the destination point for most of the customer service jobs outsourced by Western companies. While Cameroon has little or no significant call center industry, there are a number of new IT-enabled services that have generated employment for many Cameroonians. These jobs can be divided into four major areas: computer training outfits, public mobile telephone centers, call centers, and services link to office automation. These broad areas comprise other smaller sectors, which are highlighted in the case studies that follow. 


\section{Case 1: Computer Training Centers}

In this case, interviews were conducted with students, instructors and administrators of computer training outfits in Buea. ICT training has become a major sub-sector in the industry in Cameroon, as is in many other SubSaharan African countries. This is driven by the demand for computer-related services and the growth of the service industry. For instance, an increasing number of micro-finance institutions and money transfer agencies are being created and all rely on computer technology for effective management and efficient service delivery. Between 2000 and 2009, more than 2,000 "cyber cafes" were established all over Cameroon to serve the approximately 90\% of Cameroonians who do not have direct connections to the Internet. Majority of "cyber cafes" are based in Yaounde, Douala, Bafoussam, Bamenda and Buea. The expansion of these services has demands for highly trained computer experts in both software and hardware to maintain the computers and perform necessary office tasks. The result of this demand is the presence of ICT training centers in many urban centers in Cameroon.

In Cameroon, ICT training was officially introduced into the curriculum of public schools in 2001 through a cyber-education project (Tetang, 2007) targeted at secondary and tertiary education. It has, over the years, successfully installed multimedia resource centers (MRC) in universities, professional and technological schools and selected secondary schools in the country. Technically, everyone (men and women) has equal access to these resources as well as the training. It has however observed that fewer women than men take advantage of the training provided in these facilities. For example, of the seven students enrolled in the master's degree program in the Department of Computer Science at the University of Buea during the 2009/2010 academic session, only one was a woman. Gender parity was observed in the doctoral program for the 2008/2009 cohort: two of the four PhD students admitted into the cohort were women.

The bulk of computer and related-IT training therefore occurs outside the formal education sector. As in many countries in Sub-Saharan Africa, the explosion in ICTs has created a mushrooming of "computer schools" in many cities and urban centers. The level of training ranges from basic typing skills to hardware maintenance. In many instances, these training centers are owned and operated by men though the student body is more diverse, with most women enrolling in software and application programs, as this research found through a study of four major computer training institutions in Buea. Most of the women in the institutions that participated in this study were enrolled in programs such as computerized accounting and secretarial training rather than computer hardware or CISCO (networking) training.

Table 2: Registration Patterns in Computer Training Centers in Buea

\begin{tabular}{|l|c|c|c|c|c|c|c|c|}
\hline \multicolumn{1}{|c|}{ Disciplines } & \multicolumn{9}{c|}{ Training Centers } \\
\hline \multirow{2}{*}{ Computerized Accounting } & \multicolumn{2}{c|}{ COIC } & \multicolumn{3}{c|}{ IVTC } & \multicolumn{2}{c|}{ EMOTECH } & \multicolumn{2}{c|}{ Design Systems } \\
\hline Information Technology (CISCO) & $\mathrm{M}$ & $\mathrm{F}$ & $\mathrm{M}$ & $\mathrm{F}$ & $\mathrm{M}$ & $\mathrm{F}$ & $\mathrm{M}$ & $\mathrm{F}$ \\
& - & 5 & 5 & 58 & - & - & - & 15 \\
\hline \multirow{2}{*}{ Secretarial duties } & 2 & 4 & 3 & 80 & - & - & - & - \\
\hline Computer Maintenance & 10 & 2 & 19 & 1 & 8 & 3 & 7 & - \\
\hline Total & 12 & 11 & 27 & 139 & 23 & 07 & 15 & 15 \\
\hline
\end{tabular}

COIC - Cameroon Opportunities Industrialization Centre. IVTC - Intensive Vocational Training Centre. EMOTECH Empowerment CISCO Networking Academy

As Table 2 shows, women who enrolled in the four training centers in Buea trained in software programming and applications rather than in hardware maintenance, generally considered as more challenging. The centers are COIC, IVTC, Emotech and Design Systems. A manager at one of the centers studied, explains that recruiters unwittingly discourage women from enrolling in the hardware programs by mystifying them through the language used to describe the courses and requirements thereby scaring away interested women. Additionally, according to some of the teachers in the training centers, women are also discouraged from enrolling in the hardware programs because the fees are higher and they require longer training time. For these reasons, only about one percent of women study computer maintenance. Even then, they are more involved in trouble-shooting rather than the physical aspects of fixing or repairing computers. Presently, MTN and Orange, two cellular phone companies in Cameroon, have hired women in their technical departments but the women merely diagnose the problem and then 
pass the equipment on to male technicians for the required repairs and/maintenance. It has been explained that women, even those trained in the hardware, are better at the front office interfacing with end-users and customers of the products.

It has also been observed that none of the ICT repair businesses in the entire South West Region is owned or operated by a woman. At the training centers studied, very few women worked as instructors with majority of the trainers being men. When women taught, they taught courses like French, English and business law rather than core IT courses. The absence of female teachers in these training programs also means absence of role models for women who might be interested. This then becomes a vicious circle. One possible reason for women's absence in training sector relates to socialization of women in Cameroon to be dependent on the men. This reduces the incentive for women to be more assertive in establishing their own ICT businesses.

\section{Case 2: Call Boxes (Public Mobile Telephone Centers)}

The mobile telephone sector in Cameroon was established in 1999 with the advent of Mobilis, now Orange. Mobilis was eventually joined by MTN and later Camtel. Within ten years of the first digital cellular service in Cameroon, mobile phone subscriptions rose to $41 \%$ (ITU, 2011). While the cumulative annual growth rate has been astronomical, more than half of the populations of 19 million people lack direct access to the Internet. Similar to the ways in which cyber cafés provide public access to the Internet, call boxes or mobile payphones also exist to provide access to calling. This sub-sector has in turn generated a new workforce of small-scale entrepreneurs (mostly male and female college graduates), suppliers of airtime (mostly men who buy large quantities of airtime and supply them to call box operators on credit). Many young people have obtained employment as call box operators or started their own call box business with a small initial capital (\$100). Majority of the workers are women, mostly aged 18-40, who are employed to run call boxes. A statistic of phone booths in Buea showed that about 80 percent of workers in 300 call boxes in the city are women.

The process of starting a call box is challenging especially for many young women who have little education and no operating capital beyond the little that family members might contribute. There are two options in starting a call box; A - large scale call box, for entrepreneurs who have capital and run a group of call boxes, or B an individual who does not have capital and invests in a single call box. To start a call box an individual needs to identify a good location (with prospects for a lot of business) and build the call box (typically a table, two hardbacked chairs and a big umbrella). After the call box is set up, the entrepreneur must purchase two hand sets and SIM cards, one for each of the major phone service providers in the region. He or she must also have enough startup capital to buy sufficient supply of airtime from a phone company to guarantee discounted call rates to increase the call box operator's profit margin. While this preparation may sound simple, many of the women interviewed during this study reported they could not afford to start their own call box business and were therefore working for other call box owners. Generally, call box operators work for a minimum of ten hours a day and are paid about 25,000FRSCFA (\$50.00) per month.

A Call box worker has the classic characteristics of a pink-collar job because of the predominance of women in the industry. Also, the pay is low and the job has no career track associated with it. For the majority of call box operators, there is no other job opportunity open to them, so they find themselves unable to negotiate better pay or working conditions.

The development of the Call box economy is not only explained by the lack of education for young women involved in, since many educated young women and men are also carrying out this activity. In other major towns like Douala and Yaoundé, the Call box activity is taken over by students as their holiday jobs, this to increase their income and cope with the fragile economic conditions of students in Cameroon. Generally speaking, Call box activity is easy to run. Therefore, the trend towards Call box activity is a consequence of the worse economic situation that Cameroon is facing with unemployment of youth between 15-24 with a constant increase going from $7.6 \%$ in 2005 to $8.2 \%$ in 2007 of youths under employed or working in the informal economy dominated by lowskilled and low-paid jobs (UNDP, National report on MDG progress, 2008). 


\section{Case 3: Call Center Work - MTN/Orange Cameroon/Spectrum}

Another area of the pink-collar ICT industry in Cameroon is at the call center. This is a highly feminized sub-sector. Call centers generally process calls from a company's customers services department and directs them to relevant departments of the business. Some call centers also engage in outside calls to customers to provide service or solicit new business (telemarketing). In Cameroon, telecom companies have in-house call centers as well as external call centers. The external call centre works on behalf of several companies. Spectrum, an advertising firm, operates such a call center. For this research, we visited the call centers of two telecommunication companies, MTN/Orange and Spectrum.

There were 224 workers at the MTN call and customer care centre. Of this number, 154 were female and 70 were male. According to one of the call center operators, call center jobs are meant for high school graduates. However, many college degree holders take up call center jobs while seeking other better opportunities. The telecommunication companies prefer women in call centers because they have more skills in customer relations, tend to be more patient and are better listeners. Call centre work is very taxing. According to some other employees at the Spectrum call centre, it gets very boring receiving the same complaints from customers and long hours on the phone can be very painful. Call centre work is also not very suitable to family life especially for women who are the majority of home makers within the family. During recruitment interviews, women are asked if they might have problems because they are married or have families. Most of them say "no" because of the desperate need for employment. Though working hours in the call centers are long and workers often have to sit in one spot for hours waiting for incoming calls, schedules runs from 07:00am - 3:00pm, 3:00pm to 11:00pm and 11:00pm - 07:00am. Men and women earn the same wages in call centers, 160.000FRSCFA (\$320.00) a month.

A further breakdown of the call centre work shows that more women than men are tele-operators. These are outbound/inbound call specialists whose work involves contacting potential customers to sell them goods and services. They are expected to make their calls in only a few minutes and must be able to determine their caller's needs using a script. They must also respond to customer inquiries while at the same time selling them some of the company's products.

Junior Secretaries; this is another Pink-collar job dominated by women. This constitutes a variety and delivery of services dealing with office automation like typing, photocopying, scanning, printing etc. The job of a junior secretary does not necessarily require a qualification, even if there are internal and tasks-oriented trainings. Young women without any knowledge or training in ICT, but with a minimum requirement in general education can work as a secretary. Salaries are not high and follow the trend of other low-skilled jobs.

\section{CONCLUSION}

Education and training have a direct impact on employment. New hires must be skilled or educated enough to contribute positively to whatever job they are employed for. In Cameroon, the degree of gender discrimination in employment for certain positions is gradually decreasing as an outcome of the entrance of many women into the ICT industry particularly in the call center jobs. However, the gender gap in the workforce persists but not as a result of overt gender discrimination but through certain socio-cultural factors that subtly exclude women from high-paying ICT jobs. One of these, as we have seen in one of the case studies is the continued mystification of ICTs as a male terrain. While the ICT training centers are providing useful training opportunities for young men and women, the government cyber education project would be expanded to mainstream ICT training in secondary schools in more gender inclusive environments. This reduces the number of women whose first encounters with ICT training occur in male-dominated ICT training centers that thrive by mystifying ICTs.

The social and cultural environments also play a significant role in women's educational choices. Women are generally looked upon as weak or ineligible for certain jobs. In the field of ICTs, computer maintenance has been privileged as a man's job. In some ways, women actually consider the actual process of dismantling a computer, replacing or removing parts and resetting it as degrading. They have been socialized to think like that and will generally make fun of any other female involved in doing it. Those who have the skills are therefore forced by social expectations not to pursue this activity. The starting point, then, is with the mindset to categorize certain jobs into male and female, especially by women themselves. 


\section{AUTHOR INFORMATION}

Manka E. Tabuwe holds a Master's Degree in Journalism and teaches in the Department of Journalism and Mass Communication in the University of Buea, Cameroon. Her areas of publishing include journalism theory and practice and women in ICTs.

Henry Z. Muluh is a Senior Lecturer and former Chair of the Department of Journalism and Mass Communication, University of Buea. His research interests include the evolution of modern mass media, media regulation, media production and online media.

Enoh Tanjong teaches in the Department of Journalism and Mass Communication, University of Buea, Cameroon. He is currently a Fulbright Scholar at ICITD, SUBR, Louisiana USA. E-mail: enoh tanjong@yahoo.com

Patience Akpan-Obong is Associate Professor of Science, Technology and Society (STS) at Arizona State University. She teaches courses in Political Science, Sociology, STS and Women's Studies. Her research interests are in information and communication technologies (ICTs) and development; gender and ICTs.

Lawrence Sikali is a doctoral student at the ICT University.

Augustine Ngongban is a doctoral student at the ICT University.

Ajibike Olubunmi Itegboje is a Chief Lecturer at the Yaba College of Technology in Nigeria and a Research Scholar in Science and Technology and Information Technology Applications.

Kibily Demba Samake is Assistant Professor of Info Systems and Decision Sciences at Louisiana State University. His research centers on the implications of information and communication technologies for developing countries particularly in the areas of healthcare information systems, and organizational systems.

Victor Wacham A. Mbarika is an Endowed Professor at SUBR and President of The ICT University. He is also Executive Director, International Center for IT and Development. He has published extensively on ICTs. E-mail: victor@mbarika.com (Corresponding author)

\section{REFERENCES}

1. Aker, Jenny C., Mbiti, Isaac M. (2010). Mobile phones and economic development in Africa. Working paper 211. Center for Global Development 2010.

2. Aker, Jenny C. (2008). Does digital divide or provide? The Impact of Mobile Phones on Grain Markets in Niger. BREAD Working Paper \# 177.

3. Akpan-Obong, Patience I. (2009). Information and communication technologies in Nigeria: Prospects and challenges for development. New York: Peter D. Lang.

4. Adeyinka, Tella, Ajiboye, Josiah, Adu, Emmanuel, Wojuade, James (2007). Stakeholders' perceptions of the impact of GSM on Nigeria's rural economy: Implication for an emerging communication industry. Community Informatics, 3,4 .

5. Arundhathi, Suchit. N., Arunachalam, Subbiah (Eds.) (2010). Transformative impact of ICT: Change stories from rural India. Jamsetji Tata National Virtual Academy (NVA) M S Swaminathan Research Foundation, Chennai.

6. Belt, Vicki R., Richardson, Ranald, Webster, Juliet (2000). Women's work in the information economy: The case of telephone call centers Information, Communication and Society, 3, 3.

7. Bury, Rhiannon (2011). "She's Geeky: The performance of identity among women working in IT." International Journal of Gender, Science and Technology, 3, 1

8. Choudhury, Naziat (2009). The question of empowerment: Women's perspective on their Internet use. Gender Technology and Development 13, 341.

9. Gill, Rosalind (2003). Speech prepared for the 47th commission on the status of women, United Nations, New York, March 3rd 2003. 
10. Gurumurthy, Anita (2004) Gender and ICTs: Overview Report. Institute of Development Studies. Retrieved on May 30, 2011 from http://www.bridge.ids.ac.uk/reports/CEP-ICTs-OR.pdf

11. Hafkin, Nancy, Taggart, Nancy (2001). Gender, information technology and developing countries: An analytic study. Academy for Educational Development (AED).United States Agency for International Development.

12. Howe, K. Louise (1977). Pink collar worker: Inside the world of women's work. New York: Putman.

13. Institute of International Studies of Missouri Southern State College (2002) The Africans. Retrieved on May 29 from http://www2.mssu.edu/International/africa/tvseries.htm

14. International Telecommunication Union (2011). The World in 2010: ICT facts and figures. Retrieved on May 29, 2011 from http://www.itu.int/ITU-D/ict/material/FactsFigures2010.pdf

15. Johnson, Nicola F. (2009). Contesting binaries: Teenage girls as technological experts. Gender Technology and Development 13: 365.

16. Kleiman, Carol (2005). Pink-collar workers have own barriers to break. Chicago Tribune Retrieved on May 30, 2011 from http://www.chicagotribune.com/

17. Klonner, Stefan, Nolen, Patrick (2008). Does ICT benefit the poor? Evidence from South Africa. Retrieved May 30, 2011 from http://privatewww.essex.ac.uk/ pjnolen/KlonnerNolenCellPhonesSouthAfrica.pdf

18. Lerner, Daniel. (1965). The Passing of Traditional Society: Modernizing the Middle East. Free Press.

19. MacKeogh, Carol, Preston, Paschal (2005). A Win Win Situation: Human Resources Perspective on Gender in the ICT workforce, SIGIS. Retrieved on May 30, 2011 from www.rcss.ed.ac.uk/sigis/public/displaydoc/full/D04_2.15_DCU3

20. Mazrui, Ali (2008). Summary of The Africans: A triple heritage. A Facebook Note posted on September 8, 2008 at 6:47 a.m. Retrieved May 29, 2010 from http://www.facebook.com/note.php?note_id=30550750145

21. Miller, Linda, Neathey Fiona, Pollard, Emma, Hill, Darcy (2004). Occupational segregation, gender gaps and skill gaps. Working Paper 15, Equal Opportunities Commission. Retrieved on May 30, 2011 from http://www.employment-studies.co.uk/pubs/summary.php?id=eocwps15

22. Ng, Cecilia, Mitter, Swasti (2005). Valuing women's voices: Call center workers in Malaysia and India. Gender Technology and Development 9: 209.

23. Nzepa, Olivier N., Keutchankeu, Robertine, T. (2007). Cameroon telecommunications sector performance review. Retrieved on December 04, 2009 from http://www.researchictafrica.net/new/images/uploads/ RIA_SPR_Cameroon 07.pdf

24. Cellular Operators Association of India (January 2005). The Ovum Report on the economic benefits of mobile services in India. Retrieved May 30, 2011 from

http://www.coai.com/docs/COAI\%20Report\%20on\%20Economic\%20Benefits\%20of\%20Mobile\%20Servi ces\%20in\%20India.pdf

25. Panteli, Niki, Stack, Janet, Ramsay, Harvie (2001). Gendered Patterns in Computing Work in the Late 1990s. New Technology, Work and Employment. 16/1 3-16.

26. Perrons, Diane (2004) Globalization and Social Change. London, UK: Routledge.

27. Pigato, Miria (2001). Information and Communication Technology Poverty, and Development in subSaharan Africa and South Asia Africa Region Working Paper Series Number 20.

28. Tetang, Tchinda (2007). ICT in Education in Cameroon. Survey of ICT and Education in Africa. Cameroon Country Report. www.infodev.org

29. UNDP, National report on MDG progress, (2008).

30. Vodafone (2005.) “Africa: The Economic Impact of Mobile Phones.” Vodafone Policy Paper Series, Number 3, online http://www.vodafone.com/etc/medialib/attachments/cr_downloads.Par.78351.File.tmp/GPP_SIM_pper_3.p $\frac{\mathrm{df}}{\mathrm{V}}$

31. Von Hellens, Liisa, Pringle, Rosemary, Nielsen, Sue, Greenhill, Anita (2000). People, Business, and IT skills: the perspective of Women IT Industry SIGC PR '2000 pp 152-157.

32. Zapf, Dieter, Bechtoldt, Myriam, Isic, Amela, Blau, Patricia. (2003). What is typical for call centre jobs? Job characteristics and service interactions in different call centers in European. Journal of Work and Organizational Psychology, 12(4), pp.311-340. 